\title{
A REVIEW ON SMALL HYDRO POWER POTENTIAL IN VIDARBHA REGION ACROSS CENTRAL INDIA
}

\author{
Charlie Fulzele \\ Asst. Prof. RGCER,Nagpur \\ E-mail : \{charliefulzele@gmail.com\}
}

\begin{abstract}
Availability of fossil fuels is real struggle now days as it is of limited in nature on Earth.Renewable energy sources are available with ample of amount with different sources like solar, wind etc. One of such renewable energy is Small Hydro which is the most emerging technology for survival and generation of electricity. Therefore Small Hydro needs to be utilized for power development. Small Hydro Power (SHP) is one of the resources available for hilly region as well as other parts of the country.SHP plants are the need for today. India has around $20000 \mathrm{MW}$ potential for large number small hydel plants in various states. Cost calculation for different SHP components has been covered in the current paper for collected data in Vidarbha region of Maharashtra State. The equation for design discharge has been formulated by considering the rivers with width, depth and the flow of water.
\end{abstract}

Key Words : Small Hydro Power Plants (SHP), renewable resources, cost analysis.

\section{Introduction}

The conventional sources of energy which are finite and therefore we must utilize the renewable sources like small hydro and solar. One of such source is SHP besides Solar, Wind, Biomass, Geothermal and Fuel Cell etc. There is tremendous scope in developing small hydro plants by constructing power projects on rivers and canals or at small dams.

The thesis in [1] covers the estimation of small, mini, micro hydro power potential in Vidharbha region of India. But the cost benching is not covered for this work. References [2] presents the cost effective designs for small hydro plant. Also civil structures are also discussed [3]. The details of SHP is mentioned in [4]. The data for work is presented in [5-6] for analysis of present work. Grid connected SHP development presented in [7-8] provides the idea for grid interfacing and rural electrification. Similar case study for river hydroelectric power plant is done in [9]. The turbine selection can done with the presented studies. The mathematical foundations for small hydro power cost analysis is presented in [10]. The vertical axis power turbine is presented in [11] and many such work are now attracting the interest of the researchers. The case study on Indian irrigation project is presented in [12]. The overall literature gives the idea to review the small hydro power potential in Vidharba region across central India.

Installed capacity of power projects decides the type of hydro power plant. Table 1.0 shows the maximum Installed Capacity of SHP.

\section{Review of Small Hydro Power Plants}

Table 1

Maximum installed capacity for SHP in different regions of the world.

\begin{tabular}{|l|l|l|}
\hline Sr.No. & Country/ Region & Installed Capacity (MW) \\
\hline 1 & India & $<25$ \\
\hline 2 & China & $<25$ \\
\hline 3 & Sri Lanka & $<10$ \\
\hline 4 & Sweden & $<1.5$ \\
\hline 5 & France & $<5$ \\
\hline 6 & European Union & $<10$ \\
\hline 7 & USA & $<30$ \\
\hline 8 & Brazil & $<30$ \\
\hline
\end{tabular}

The Small Hydro in India is classified as bellow by Ministry of New and Renewable Energy (MNRE) and Central Electricity Authority (CEA) according to Power generation.

Table 2

Classification of SHP in India [5]

\begin{tabular}{|l|l|l|}
\hline $\begin{array}{l}\text { Sr. } \\
\text { No. }\end{array}$ & $\begin{array}{l}\text { Classification of Small } \\
\text { Hydro }\end{array}$ & Power (kW) \\
\hline 1 & Micro Hydro & Upto $100 \mathrm{~kW}$ \\
\hline 2 & Mini Hydro & $101-2000 \mathrm{~kW}$ \\
\hline 3 & Small Hydro & $2001-25000 \mathrm{~kW}$ \\
\hline
\end{tabular}


Following table shows region wise installed hydro capacity.

Table 3

Installed hydro capacity

\begin{tabular}{|l|l|}
\hline Region & Installe capacity (mw) \\
\hline Northern & 18376.78 \\
\hline Eastern & 4378.12 \\
\hline Western & 7447.50 \\
\hline Southern & 11689.03 \\
\hline North eastern & 1242 \\
\hline
\end{tabular}

In Maharashtra State 255 sites are identified with the 732.63MW potential of SHP. Out of it 39 sitesare already installed with $263.825 \mathrm{MW}$ potential and 15 sites for 51.7 MW, according to MNRE. Looking at this, there are different programs are carried out for the development of SHP. Financial assistance is given for resource assessment of new sites, setting up new SHP, renovation and modernization of project and research and development etc.

\subsection{Central Government Policy for $\mathrm{SHP}$}

India is the 3rd largest energy generator in the world, accounting for $4.8 \%$ of the global energy generation. Government is promoting in many ways to the SHP installation and operation. Government seeks private involvement in this sector by providing institutional mechanism.

\subsection{Government of Maharashtra Policy for Private sectorabout SHP.}

Govt. of Maharashtra is promoting the SHP through private partnership involvement. The new policy of Govt. has encouraged private participation of both the Captive Power Producers (CPPs) and Independent Power Producers (IPPs) in development of SHP in State.

The main objectives for the policy are:

1. Involvement of private sector

2. Harness green power

The list of sites of SHPS to be offered for privatization is available with (Govt. of Maharashtra, Water Resources Department (GoMWRD).

The Small Hydro Power allotted under the policy shall be on Build, Operate \& Transfer Basis (BOT). This BOT period starts from commissioning of the project and of 30 years duration. At the end of BOT the absolute ownership of SHP along with land, switchyard \& allied equipment shall automatically stand transferred to Govt. of Maharashtra (GoMWRD).

The letter of permission (LoP) will empower the developer to prepare Techno-Economic Feasibility Report (TEFR). Developer need to submit the TFER to
GoMWRD within three months. After Letter of Allotment (LoA) developer shall sign the Hydro Power Development Agreement. After this he shall sign Energy wheeling agreement with Transmission entity/ distribution licensee.

Alternate Hydro Energy Centre (AHEC) is the unique research centre as well as consultancy in India which is established by the Ministry of New and renewable resources at I.I.T.Roorkee. It deals with the renewable energy resources available\& emerging technologies. In India AHEC specifically deals with the Small Hydro development and installation as well as testing. The first real time SHP simulator is installed in country at AHEC.

Following are the working areas of AHEC:

a) Survey and investigation

b) Preparation of Detailed Project Report (DPR)

c) Project design

d) Installation and commissioning of SHPs etc.

\section{Selection of Turbine for SHP based on Ns i.e. Specific} Speed

While selection of turbine at potential site we need to very careful, so some standard values of specific speed are given for selection. Fig.1. shows the application of Turbine.

Table 4

Selection of Turbine based on Specific Speed[9]

\begin{tabular}{|c|l|l|}
\hline Sr.No. & Turbine Type & Specific Speed $\mathbf{N}_{\mathbf{s}}$ \\
\hline 1 & Pelton & $12-30$ \\
\hline 2 & Turgo & $20-70$ \\
\hline 3 & Cross Flow & $20-80$ \\
\hline 4 & Francis & $80-400$ \\
\hline 5 & Propeller & $340-1000$ \\
\hline
\end{tabular}

Table 5

Selection of Turbine based on range of Head[10]

\begin{tabular}{|c|l|l|}
\hline Sr. No. & Turbine Type & Head $(\mathbf{M})$ \\
\hline 1 & Kaplan and Propeller & $2<$ Hnet $<40$ \\
\hline 2 & Francis & $25<$ Hnet $<350$ \\
\hline 3 & Pelton & $50<$ Hnet $<1300$ \\
\hline 4 & Crossflow & $5<$ Hnet $<200$ \\
\hline 5 & Turgo & $50<$ Hnet $<250$ \\
\hline
\end{tabular}

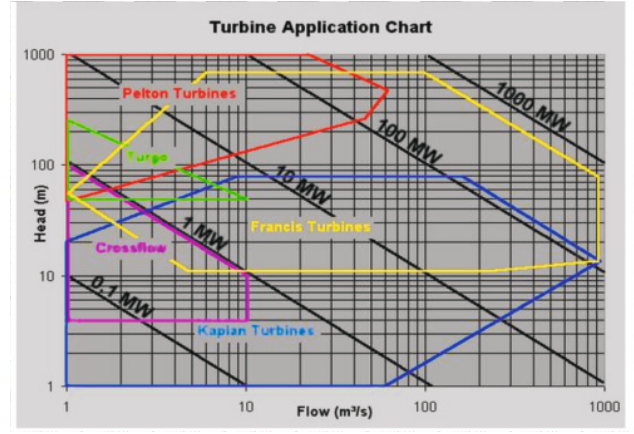

Fig. 1 : Application of Turbine[10] 


\subsection{Componentsof SHP projects:[4]}

\subsubsection{Diversion Weir}

Diversion Weir is constructed to divert the river water towards intake channel. It must be constructed in such a way that it diverts all the lean season flows and structure stands safe during floods.

\subsubsection{Feeder cum Power Channel}

\subsubsection{Disilting cum Forbay tank}

It is constructed to remove pebbles and coarse suspended material to prevent erosion of turbine blades.

\subsubsection{Penstock Pipe}

The penstock is used to feed water to power house. Penstock is made up of mild steel, fibre glass or PVC depending upon conditions.

\subsubsection{Power House}

In Power House following equipment are installed:

a) Turbine generation control panels

b) Auxiliary equipment.

\subsection{Equation tocalculate the discharge.}

The equation for calculating the discharge is given below:

Discharge $=(26.11 *$ width $*$ depth $) /$ time for float $(1)$

\subsection{Discharge calculation with available data}

Refer Table 1.0 where the data is collected for various potential available forVidarbha in Maharashtra State which includes seven districts.

\subsection{Cost Calculations}

The cost of various components mentioned above is calculated based on the reference paper and then the cost approximate for the SHP with some constraints is calculated. Table 2.0 gives the details. Cost per $\mathrm{kW}$ is calculated for small hydro power potential of Vidarbha region based on following formula [11] and accordingly different graphs are plotted.

$\mathrm{C}=6.882 \mathrm{H}^{-0.0782} \mathrm{P}^{0.6369}(2)$

Where,

$\mathrm{C}=$ Cost per $\mathrm{kW}$ in Indian Rupees

$\mathrm{H}=\mathrm{Head}$ in meter

$\mathrm{P}=$ Capacity in $\mathrm{kW}$

\section{Result and Discussion}

Approximate cost of given components of small hydro power plants which can be installed are calculated for identified sites of Vidarbha.

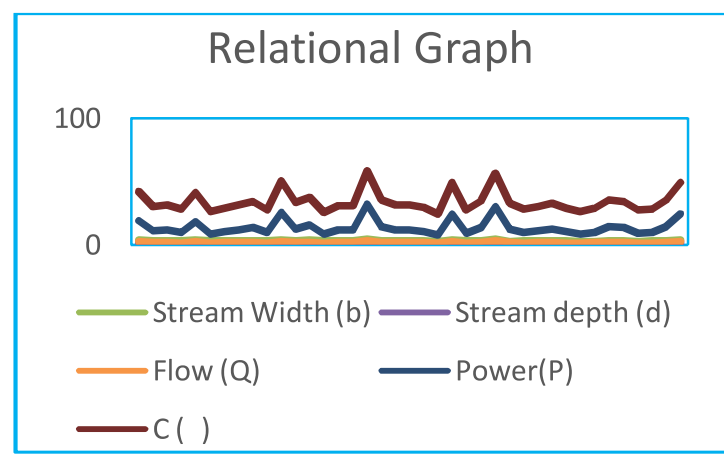

Fig. 2 : Relational Graph

Relational Graph shown in Fig. 2 is obtained by the calculation of cost per $\mathrm{kW}$ using formula (1-2) which indicates the variation of Power with respect to Cost.

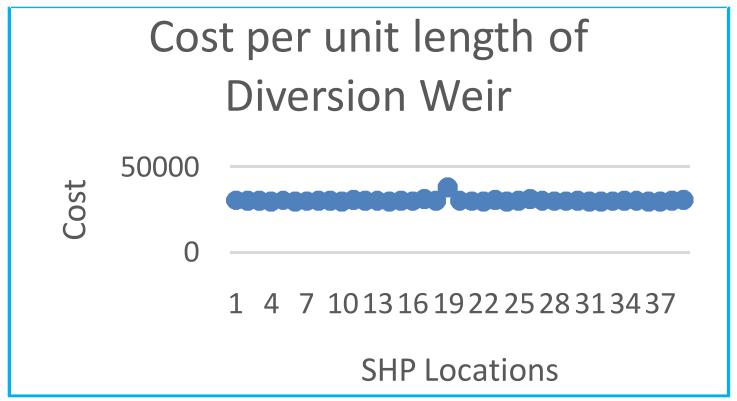

Fig. 3 : Cost per unit length of Diversion Weir

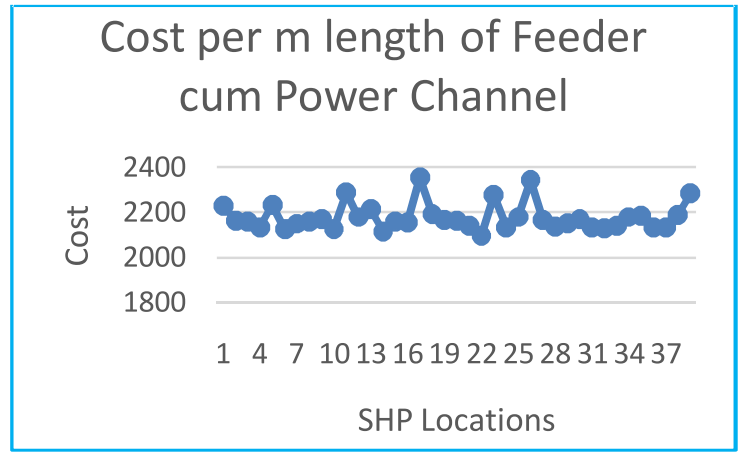

Fig. 4 : Cost per $m$ length of Feeder

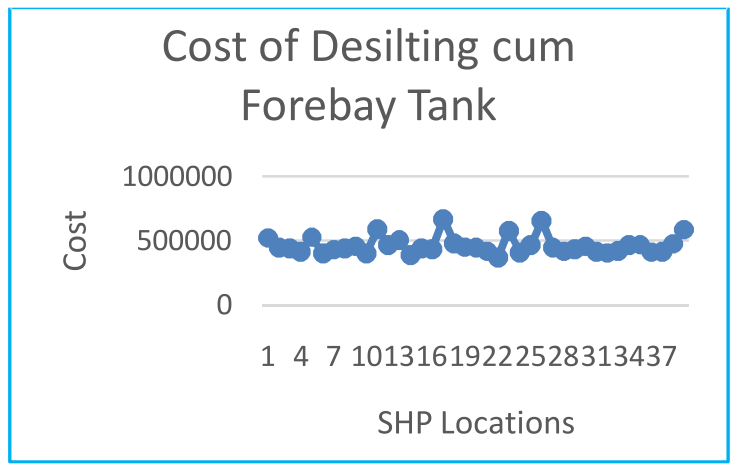

Fig. 5 : Cost of Disilting Tank 


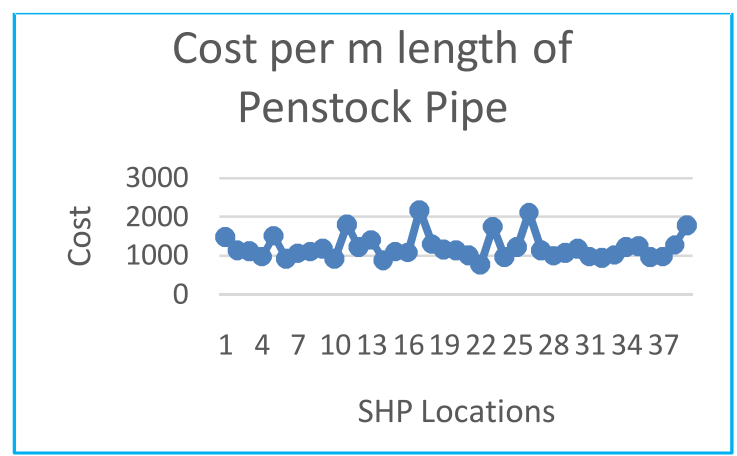

Fig 6 : Cost per $m$ length of Penstock

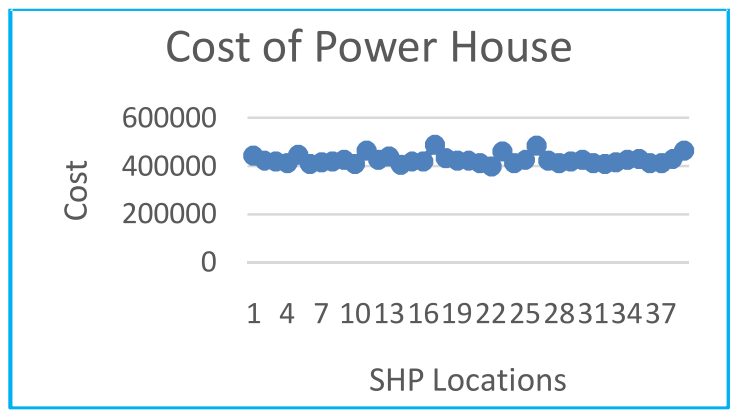

Fig. 7 : Cost of Power House

Figures 3,4,5,6 and 7 gives the details of the cost of various components against the locations of SHPs located in Vidarbha region.

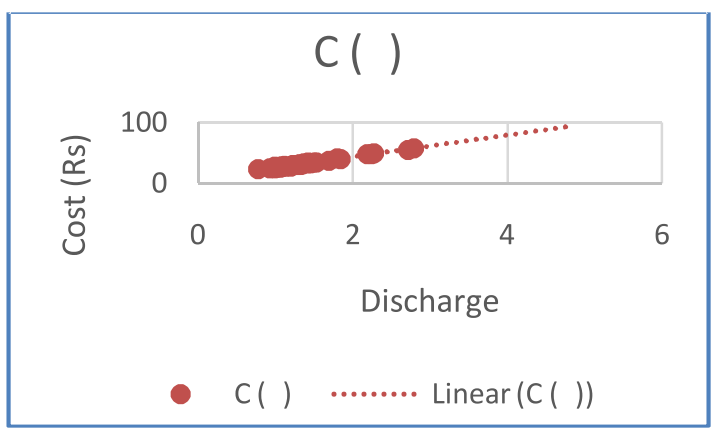

Fig. 8 : Discharge Vs. Cost

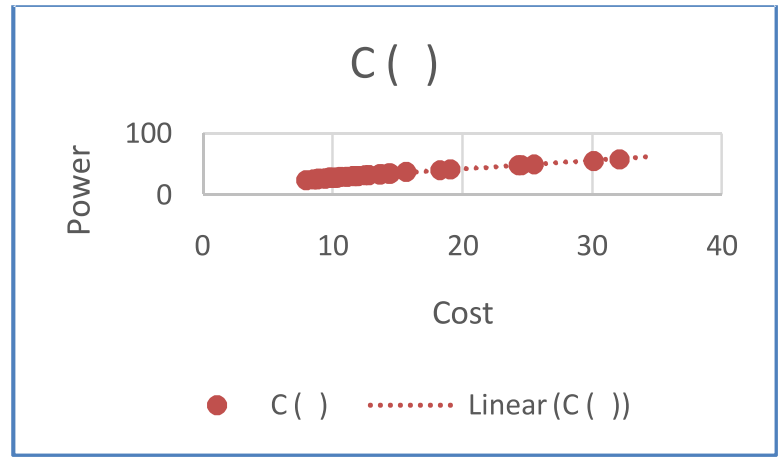

Fig. 9 : Power Vs. Cost

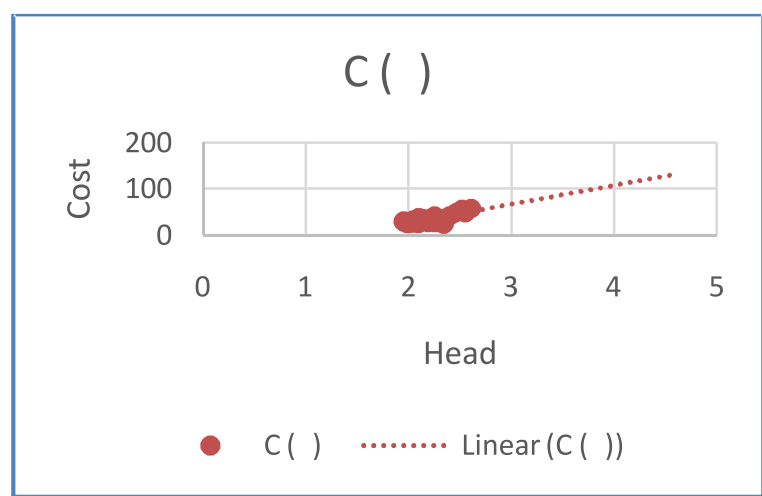

Fig. 10 : Head Vs. Cost

Figures 8, 9 and 10 compares the values of Head, Power and Cost which are calculated using equation (2).

\section{Conclusion}

Based on the study done and observations obtained with various references the small hydro power sites i.e. the sites which are below $25 \mathrm{MW}$ are identified and the potential are known. The review has taken based on various references to obtain various parameters. In this paper attempt is made to calculate cost of components and cost per kW for 39 SHP sites

\section{References}

[1] ShrikantGajbhiye, B.Tech. Thesis on "Estimation of small, mini, micro hydro power potential of Vidarbha using small irrigation dams and canals", dept. of Mech. Engineering, VNIT, Nagpur, July 2017.

[2] Shrish Gupta, M.Tech. Thesis on "Cost Effective Design for Micro Hydro Schemes" AHEC, IIT Roorkee in 2002.

[3] Singhal MK, Kumar A. Cost benching for civil structures of micro/mini hydro electric projects located in Uttaranchal. Himalayan small hydro summit, Dehradun. 2006 Oct 12:381-90.

[4] D.P. Kothari,K.C.Singhaland .RakeshRanjan, Book "Renewable Energy Sources and Emerging Technologies".

[5] http://www.mnre.gov.in/prog-smallhydro.htm

[6] http://www.ireda.gov.in/Compendium/ Data/ Maharashtra/SHP.pdf

[7] Bajaj, Jagmohan Lal, Namrata Mukherjee, and Ashish V. Kulkarni. "Grid-connected small hydropower (SHP) development: Regulatory issues and challenges." In International Conference on Small Hydropower, Hydro Sri Lanka, pp. 22-24. 2007 
[8] Michael, P.A. and Jawahar, C.P., 2017. Design of $15 \mathrm{~kW}$ Micro Hydro Power Plant for Rural Electrification at Valara. Energy Procedia, 117, pp.163-171.

[9] Temiz, Aktan. "Decision making on turbine types and capacities for run-of-river hydroelectric power plants a case study on Eglence-1 HEPP." Master's thesis, İzmir Institute of Technology, 2013.

[10] Mishra, Sachin, S. K. Singal, and D. K. Khatod. "Costing of a small hydropower projects." International Journal of Engineering and Technology 4, no. 3 (2012): 239.

[11] Chen, J., Yang, H. X., Liu, C. P., Lau, C. H., \& Lo, M. (2013). "A novel vertical axis water turbine for power generation from water pipelines. Energy, 54, 184-193."
[12] Adhau, S.P., Moharil, R.M. and Adhau, P.G., 2012. Mini-hydro power generation on existing irrigation projects: Case study of Indian sites. Renewable and Sustainable Energy Reviews, 16(7), pp.4785-4795.

[13] Adhau, Mrs SP, R. M. Moharil, and P. G. Adhau. "Estimation of micro hydro power plant capacity from potential sites." In Power Electronics, Drives and Energy Systems (PEDES), 2012 IEEE International Conference on, pp. 1-5. IEEE, 2012.

[14.] Killingtveit, Ånund. "Hydropower."Managing Global Warming. Academic Press, 2019. 265-315. 